\title{
From IHF protein to design and synthesis of a sequence-specific DNA bending peptide
}

\author{
Eduard Liebler and UIf Diederichsen* \\ Institut für Organische und Biomolekulare Chemie, Universität Göttingen, \\ Tammannstraße 2, D-37077 Göttingen, Germany
}

\section{Experimental Part}

HPLC analysis was carried out using a P900 liquid chromatography instrument (Pharmacia Biotech). UV absorption was detected at 214 and $254 \mathrm{~nm}$. Chromatographic conditions are given with specific examples. For preparative HPLC purification an YMC column Jsphere ODS/H80 25cm, $250 \times 25 \mathrm{~mm}, 5 \mu \mathrm{m}, \mathrm{C}$ 18 was used. HPLC-solvents: A: $0.1 \%$ TFA in water, B: $10 \%$ water, $0.1 \%$ TFA in acetonitrile; flow rate: $1 \mathrm{~mL}$ $\mathrm{min}^{-1}$. Positive ion electrospray mass spectra were recorded on a Finnigan LCQ mass spectrometer. Positive high resolution mass spectra were recorded on a Bruker FTMS-7 APEX ${ }^{\circledR}$ IV 70e FT-ICR mass spectrometer. The isotope distribution observed for mass spectral ions is consistent with data calculated from isotopic abundances. For automatic SPPS a peptide synthesizer model 433 A from Applied Biosystems was used. Generally the FastMoc $0.10 \mathrm{mmol}$ (amount of resin) Fmoc standard protocol in an $8 \mathrm{~mL}$ reaction vessel was used; modifications like extended coupling times or double coupling are indicated.

Synthesis of the three generation lysin dendrimer connected to a poly glycine linker.

The lysine based dendrimer-linker-construct $\mathbf{2}$ was synthesized according to the Fmoc standard protocol (FastMoc $0.10 \mathrm{mmol}$ ). The automatic synthesis protocol was modified omitting the final deprotection step which is normally included. Dendrimer 2 was cleaved from the resin using $5 \mathrm{~mL} \mathrm{30 \%} \mathrm{HFIP} \mathrm{in} \mathrm{DCM} \mathrm{for} 45 \mathrm{~min}$ at room temperature. After HPLC purification ( 5 to $41 \%$ B in 20 $\left.\min , R_{\mathrm{t}}=18.72 \mathrm{~min}\right)$ an overall yield of $60 \%(110 \mathrm{mg}, 60$ $\mu \mathrm{mol})$ was obtained. MS: ESI $m / z$ 914.4 $\left([\mathrm{M}+2 \mathrm{H}]^{2+}\right.$, 100), $1826.9\left([\mathrm{M}+\mathrm{H}]^{+}, 15\right)$, HR ESI MS $\mathrm{C}_{84} \mathrm{H}_{155} \mathrm{~N}_{21} \mathrm{O}_{23}$ $[\mathrm{M}+\mathrm{H}]^{+}$calculated 1826.16041 found 1826.16141, $[\mathrm{M}+2 \mathrm{H}]^{2+}$ calculated 914.08748 found 914.08762, $[\mathrm{M}+3 \mathrm{H}]^{3+}$ calculated 609.72742 found 609.72795 , $[\mathrm{M}+4 \mathrm{H}]^{4+}$ calculated 457.54738 found 457.54753 .

Synthesis of the cyclic peptide 5 and subsequent connection to dendrimer 2 .
The linear precursor 4 of the cyclic peptide was assembled according to the Fmoc standard protocol (FastMoc $0.10 \mathrm{mmol}$ ). During synthesis Fmoc-L-proline and its enantiomer were double coupled. This time the final deprotection step was carried out to prepare peptide 4 for cyclization. Cleavage from the resin was achieved with $5 \mathrm{~mL} \mathrm{30 \%} \mathrm{HFIP} \mathrm{in} \mathrm{DCM} \mathrm{for} 45 \mathrm{~min}$ at room temperature. Afterwards the resin was washed again with $2 \mathrm{~mL} \mathrm{30 \%} \mathrm{HFIP} \mathrm{in} \mathrm{NMP.} \mathrm{The} \mathrm{crude} \mathrm{peptide} 4$ was precipitated from cold ether, centrifuged and purified by HPLC (50 to $100 \% \mathrm{~B}$ in $30 \mathrm{~min}, R_{\mathrm{t}}=20.91 \mathrm{~min}$ ) to give an overall yield of $69 \%(146 \mathrm{mg}, 69 \mu \mathrm{mol})$ (Figure 1). MS: ESI $m / z 2115.6\left([\mathrm{M}+\mathrm{H}]^{+}, 100\right)$ HR ESI MS $\mathrm{C}_{105} \mathrm{H}_{154} \mathrm{~N}_{18} \mathrm{O}_{26} \mathrm{~S}[\mathrm{M}+2 \mathrm{H}]^{2+}$ calculated 1058.55740, found 1058.55737. Cyclization was carried out under argon. The linear precursor 4 was dissolved to $10^{-3}$ to $10^{-4} \mathrm{M}$ in dry DMF/DCM (1/9). Then 10 equiv. DIC, 1 equiv. HOAt and 3 equiv. NMM were added. The reaction was stirred for $12 \mathrm{~h}$ at room temperature. After removal of solvents the residue was dissolved in methanol and purified by HPLC (70 to $100 \% \mathrm{~B}$ in $30 \mathrm{~min}, R_{\mathrm{t}}=31.95$ min) to yield $37 \%(54 \mathrm{mg}, 26 \mu \mathrm{mol})$ of peptide 5 . MS: ESI $m / z \quad 1049.9\left([\mathrm{M}+2 \mathrm{H}]^{2+}, 100\right), \quad$ HR ESI MS $\mathrm{C}_{105} \mathrm{H}_{152} \mathrm{~N}_{18} \mathrm{O}_{25} \mathrm{~S}[\mathrm{M}+2 \mathrm{H}]^{2+}$ calculated 1049.55211, found 1049.55233. After lyophilization cyclic peptide $\mathbf{5}$ was dissolved in dry DMF and 40 equiv. of $\mathrm{Me}_{2} \mathrm{NH} \cdot \mathrm{BH}_{3}$ and 0.1 equiv. $\mathrm{Pd}\left(\mathrm{PPh}_{3}\right)_{4}$ were added to remove the Alloc protection of the Dap side chain. The reaction was kept under argon and stirred at room temperature for $15 \mathrm{~min}$. Two repetitions were performed. After removing of DMF, HPLC purification ( 70 to $100 \% \mathrm{~B}$ in $30 \mathrm{~min}, R_{\mathrm{t}}=$ $16.92 \mathrm{~min})$ yielded $56 \%(30 \mathrm{mg}, 15 \mu \mathrm{mol})$ of 3 . MS: ESI $m / z \quad 1007.8 \quad\left([\mathrm{M}+2 \mathrm{H}]^{2+}, \quad 100\right), \quad$ HR $\quad$ ESI MS $\mathrm{C}_{101} \mathrm{H}_{148} \mathrm{~N}_{18} \mathrm{O}_{23} \mathrm{~S}[\mathrm{M}+2 \mathrm{H}]^{2+}$ calculated 1007.54155 found 1007.54135. Under argon 2.5 equiv. of the dendrimer 2 were then coupled to the cyclic part 3 by 8 equiv. DIC and 3 equiv. HOAt ( $0.5 \mathrm{M}$ in DMF) together with 3 equiv. of NMM as base in dry DMF. After removing solvents, purification by HPLC (50 to $100 \% \mathrm{~B}$ in $30 \mathrm{~min}, R_{\mathrm{t}}=$ $12.75 \mathrm{~min})$ yielded $36 \%(21 \mathrm{mg}, 5.50 \mu \mathrm{mol})$ of 6 . MS: ESI $m / z 1911.2\left([\mathrm{M}+2 \mathrm{H}]^{2+}, 100\right), 3822.6\left([\mathrm{M}+\mathrm{H}]^{+}, 5\right)$, 
HR ESI MS $\mathrm{C}_{185} \mathrm{H}_{301} \mathrm{~N}_{39} \mathrm{O}_{45} \mathrm{~S} \quad[\mathrm{M}+3 \mathrm{H}]^{3+}$ calculated 1274.74676, found 1274.74671, $[\mathrm{M}+4 \mathrm{H}]^{4+}$ calculated 956.31189, found 956.31156. All permanent side chains were deprotected with $95 \%$ aq. TFA. After purification by HPLC ( 3 to $40 \%$ B in $30 \mathrm{~min}, R_{\mathrm{t}}=14.03 \mathrm{~min}$ ), $75 \%$ (11 mg, $4.13 \mu \mathrm{mol})$ of target molecule 1 was obtained (Figure 1). MS: ESI $m / z 1330.0\left([\mathrm{M}+2 \mathrm{H}]^{2+}, 100\right), 2659.0$ $\left([\mathrm{M}+\mathrm{H}]^{+}, 7\right)$, HR ESI MS $\mathrm{C}_{116} \mathrm{H}_{207} \mathrm{~N}_{39} \mathrm{O}_{32}[\mathrm{M}+3 \mathrm{H}]^{3+}$ calculated 887.19959, found 887.19932, [M+4H $]^{4+}$ calculated 665.65151, found 665.65184, $[\mathrm{M}+5 \mathrm{H}]^{5+}$ calculated 532.72266, found 532. 72291 .

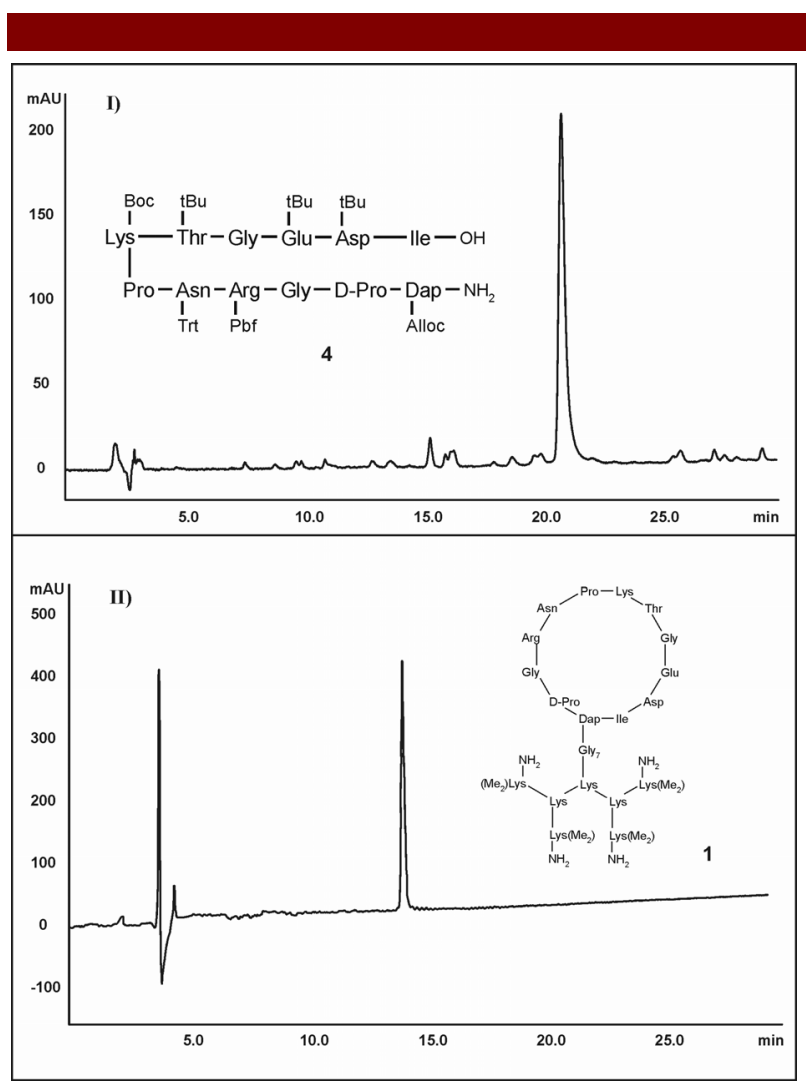

Figure 1 I) Analytical HPLC chromatogram of the crude peptide 4. Gradient: 50 to $100 \% \mathrm{~B}$ in $30 \mathrm{~min}, 254 \mathrm{~nm}$. II) Analytical HPLC chromatogram of the target molecule $\mathbf{1}$. Gradient: 3 to $40 \%$ B in $30 \mathrm{~min}, 214 \mathrm{~nm}$. Column: YMC ODSA $(250 \times 4.6 \mathrm{~mm}, 5 \mu \mathrm{m}, \mathrm{C}-18)$; solvents: A: $0.1 \%$ TFA in water, B: $10 \%$ water, $0.1 \%$ TFA in acetonitrile; flow rate: $1 \mathrm{~mL} \mathrm{~min}^{-1}$.

\section{Electrophoresis}

Gel mobility shift assays (PAGE) were accomplished to prove the non-specific electrostatic interactions of lysine dendrimers with double stranded DNA. Therefore, the aggregation of dendrimer $\mathbf{2}$ (three generation dendrimer with glycine linker) as well as dendrimers $\mathrm{Lys}_{2}$ Lys $\beta$-Ala-OH (two generation dendrimer) and $\mathrm{Lys}_{4} \mathrm{Lys}_{2} \mathrm{Lys}-\mathrm{OH}$ (three generation dendrimer without linker) with a $12 \mathrm{bp}$ random sequence $\left({ }^{5}\right.$ GCGAAAAAAGCG $\left.^{3{ }^{5}}\right)$ and the $34 \mathrm{bp}$ consensus sequence

( ${ }^{5}$ TAAAAAAGCATTGCTTATCAATTTGTTGCAACG $\mathrm{A}^{3}$ ) of the DNA-IHF complex were investigated (Figures 2 and 3). For all dendrimers a non-specific binding to DNA was indicated by disappearance of the ds-DNA band.

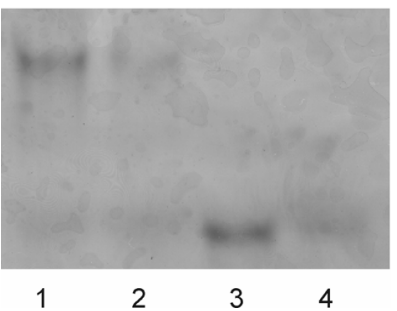

Figure 2 Gel mobility shift assay for non-specific binding of dendrimer 2 to $12 \mathrm{bp}$ ds-DNA (random sequence) (lane 1 and 2) and 34bp ds-DNA (consensus sequence) (lane 3 and 4). $200 \mu \mathrm{M}$ peptide 2 in lanes 2 and 4 , respectively.

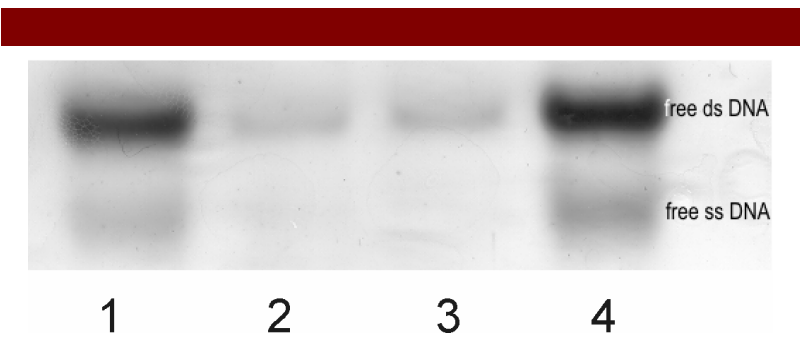

Figure 3 Gel mobility shift assay for non-specific binding of $\mathrm{Lys}_{2} \mathrm{Lys} \beta-\mathrm{Ala}-\mathrm{OH}$ (lane 2) and $\mathrm{Lys}_{4} \mathrm{Lys}_{2} \mathrm{Lys}-\mathrm{OH}$ (lane 3) to $34 \mathrm{bp}$ ds-DNA (consensus sequence). Lane 1 and 4 only dsDNA. 250 pM peptide in lanes 2 and 3, respectively.

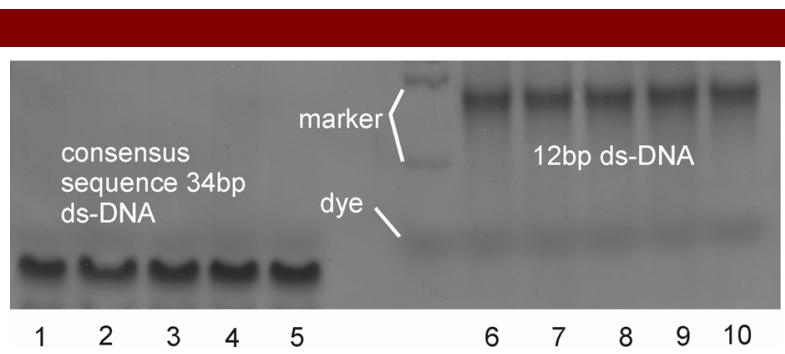

Figure 4 Gel mobility shift assay for no binding affinity of the linear decapeptide GRNP(65)KTGEDI ( $\alpha$-subunit cut) to $34 \mathrm{bp}$ ds-DNA (consensus sequence) and 12bp ds-DNA (random sequence). Lane 1-5: 34bp ds-DNA, lane 2: Ac-

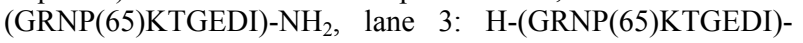
$\mathrm{NH}_{2}$, lane 4: H-(GRNP(65)KTGEDI)-OH. Lanes 6-10: 12 bp ds-DNA, lane 7: Ac-(GRNP(65)KTGEDI)-NH $\mathrm{NH}_{2}$, lane 8: H- 
(GRNP(65)KTGEDI)-NH $\mathrm{N}_{2}$, lane 9: H-(GRNP(65)KTGEDI)OH. $500 \mathrm{pM}$ peptide in lanes 2-4 and 7-9.

Furthermore, three linear decapeptides Ac(GRNP(65)KTGEDI)-NH $\mathrm{NH}_{2}$ H-(GRNP(65)KTGEDI)$\mathrm{NH}_{2}, \quad \mathrm{H}-(\mathrm{GRNP}(65) \mathrm{KTGEDI})-\mathrm{OH}$ were investigated (Figure 4). The sequence was derived directly from the minor groove binding part of IHF $\alpha$-subunit surrounding the intercalating Pro(65). The peptides differ in their Cand N-termini. No binding was indicated for all three peptides to the consensus sequence (34bp DNA) nor to the $12 \mathrm{bp}$ DNA random sequence. 